\title{
Examination of Teachers' Perceptions of Individual Values in Their Workplaces: A Case of Burdur Province
}

\author{
Barbaros Serdar Erdogan ${ }^{1}$ \\ ${ }^{1}$ Faculty of Sport Sciences, Mehmet Akif Ersoy University, Burdur, Turkey \\ Correspondence: Barbaros Serdar Erdogan, Faculty of Sport Sciences, Mehmet Akif Ersoy University, Burdur, \\ Turkey. E-mail: bserdogan@mehmetakif.tr
}

Received: December 28, 2019 Accepted: March 3, 2020 Online Published: April 2, 2020

doi:10.5539/jel.v9n3p27 URL: https://doi.org/10.5539/jel.v9n3p27

\begin{abstract}
The purpose of the research is to reveal the individual values perceptions of the teachers working in the Burdur Provincial Directorate of National Education operating under the body of the Ministry of National Education. Participants comprised 131 male and 169 female teachers. When the mean and standard deviation values regarding the teachers' perceptions of individual values in their workplaces were examined, it was seen that they agreed with the discipline and responsibility dimension, they were undecided about the trust and forgiveness dimension, and they agreed with the honesty and sharing dimension as well as the respect and truth dimension. When perceptions were examined according to range values for the respect and truth dimension, there were significant differences the trust and forgiveness dimension and the sharing and respect dimension. Accordingly, male teachers' perception levels in the trust and forgiveness dimension were significantly higher than the levels of the female teachers. On the other hand, the perception levels of the female teachers in the sharing and respect dimension were significantly higher than the levels of the male teachers. The perception levels of the single teachers in the trust and forgiveness dimension were significantly higher than the levels of the married teachers. On the other hand, the perception levels of the married teachers in the sharing and respect dimension were significantly higher than the levels of the single teachers. According to the results that we evaluated by the task type variable, a significant difference between groups was observed only in the trust and forgiveness dimension. Accordingly, the perception levels of the contracted teachers in the trust and forgiveness dimension were significantly higher than the levels of the permanent teachers.
\end{abstract}

Keywords: teachers, individual values

\section{Introduction}

The concept of value, with its most general definition, is a feature which determines the importance of events or objects for a society or an individual (Sayrac, 2016). Individual values reflect the generalisations related to culture at the social level and how administrative practices and institutional behaviours are affected based on cultural profiles (Hofstede, 2001). Values are the criteria that guide behaviours. They show likes, preferences, and undesired situations depending on what is important for individuals (Smith, 1969). When the concept of value is considered as an important factor directing behaviours, it refers to a stable belief that a particular behaviour or life purpose is superior to another and expresses the superiority of one object or situation over another (Kluckhohn, 1951). Hofstede (2001), who conducts intercultural researches on values, states that value is a great tendency towards preferring certain situations over others (Allport et al., 1960). Individual values are important in terms of explaining human behaviors. Many fields such as psychology, anthropology are intensively studied. The study conducted by Allport, Vernon and Lindzey (1951) was the first study addressing values in a tangible way by associating them with daily activities (such as reading newspapers, watching movies, and voting) (Tekeli, 2017). When a child matures, he or she attends social environments where one value competes with other values. For example, he or she may need to make a choice among problems or questions such as "what is better? Being hard-working, staying honest, being independent and being obedient for achievement or making an effort or being accepted in the social environment for self-respect? In such problems that the individual confronts in gaining step-by-step experiences and progressing into adulthood, values are arranged in order of priority or importance and they find their places in a hierarchical order. As a result, problems are solved by integrating the instrumental and terminal values learned (Rokeach, 1973). In the classification of Feather (1991), there are five 
main dimensions of values. These dimensions are; accomplishment, individualism (hedonism), universalism, serenity and benevolence;

a. Accomplishment: Represents the success tendency based on social standards and being an individual who is successful, competent, ambitious and influential.

b. Individualism (Hedonism): Represents adopting individual gratification and pleasure as a principle beyond social standards and enjoying life.

c. Universalism: It is the value of being understanding, tolerant and protecting the welfare of all people and nature. This value represents open-mindedness, virtue and social justice.

d. Serenity: Represent the continuity of relations existing in the society and the peace of the individual.

e. Benevolence: Represents looking after and improving the welfare of the society to which the individual belong and the people who are close to him or her (Feather, 1991; Basol et al., 2012).

Individuals have many values at different degrees. The values considered important for some individuals will not be important for others (Schwartz, 1992).

\section{Method}

\subsection{Participants}

300 teachers in total, as 131 male, 169 female, 267 permanent and 33 contacted, selected with the Random method from the teachers working in the Burdur Provincial Directorate of National Education operating under the body of the Ministry of National Education, participated in the research.

\subsection{Materials}

In the research, the Personal Values Inventory Scale Asan et al. (2012) developed by Roy (2003) and the Individual Values Inventory which took its final form with the linguistic equivalence validity and reliability study of this inventory by Asan et al. (2008) were used for determining the individual values of the participants (Roy, 2003).

\subsection{Procedure}

In the research, SPSS 21.0 program was used for the analysis of the data collected. In the analysis of the research data, arithmetic mean, frequency, standard deviation and percentage values, which are descriptive statistics, were examined. In order to determine whether parametric analyses would be performed for this research, firstly, it was examined whether the data of both scales showed normal distribution. The kurtosis and skewness values were calculated as a result of the analysis and the results are given below.
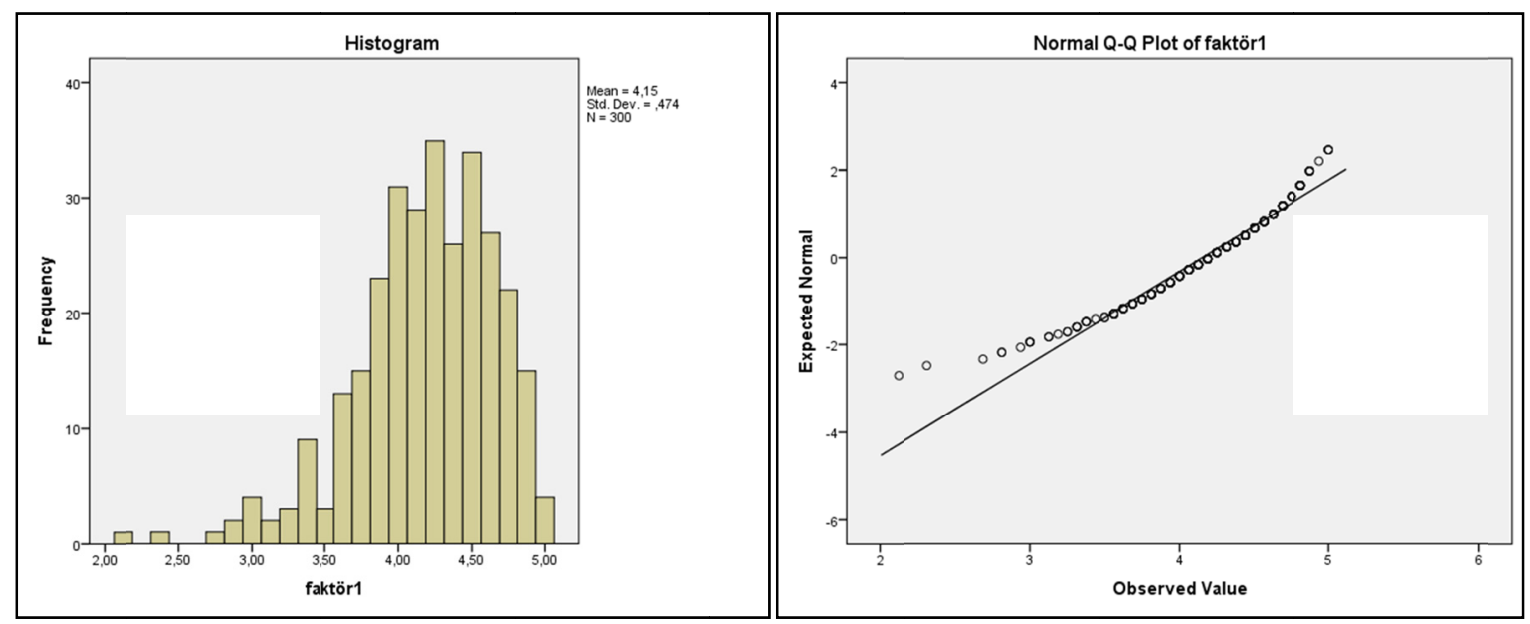

Figure 1. Factor 1 normal distribution charts for Discipline and Responsibility Dimension 


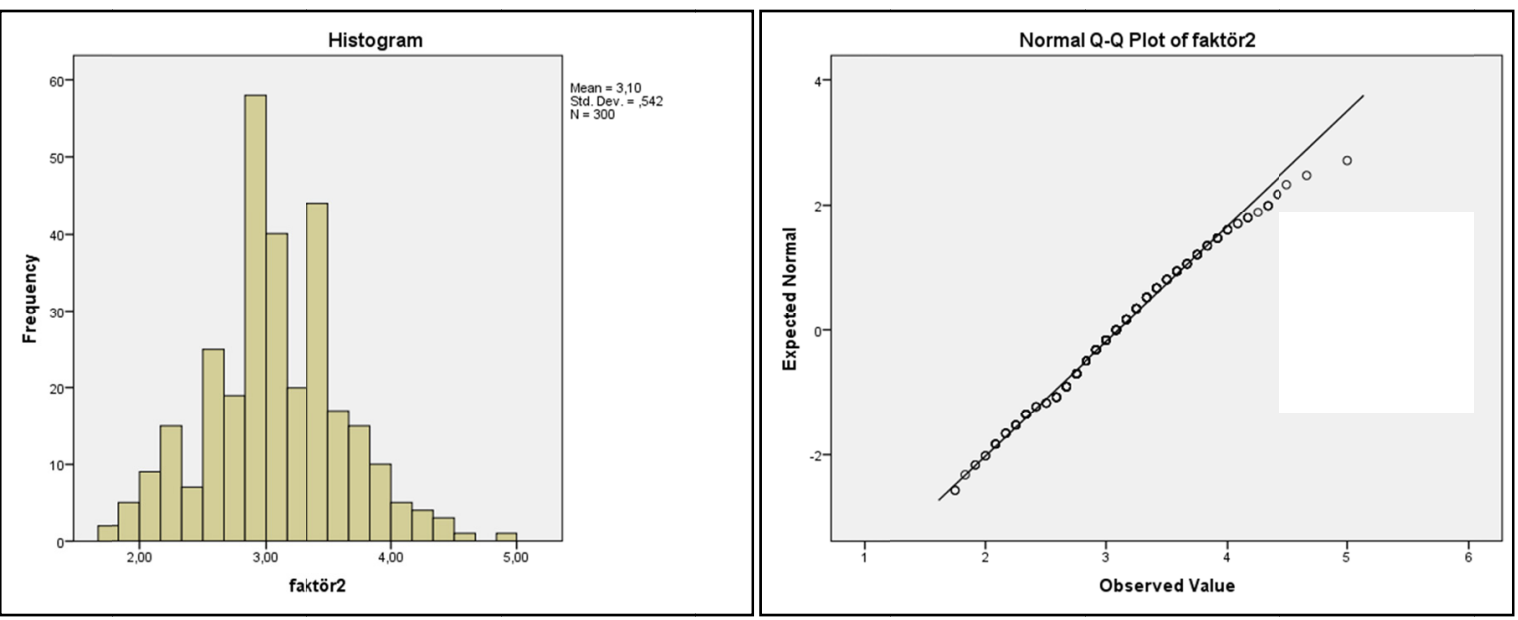

Figure 2. Factor 2 normal distribution charts for Trust and Forgiveness Dimension
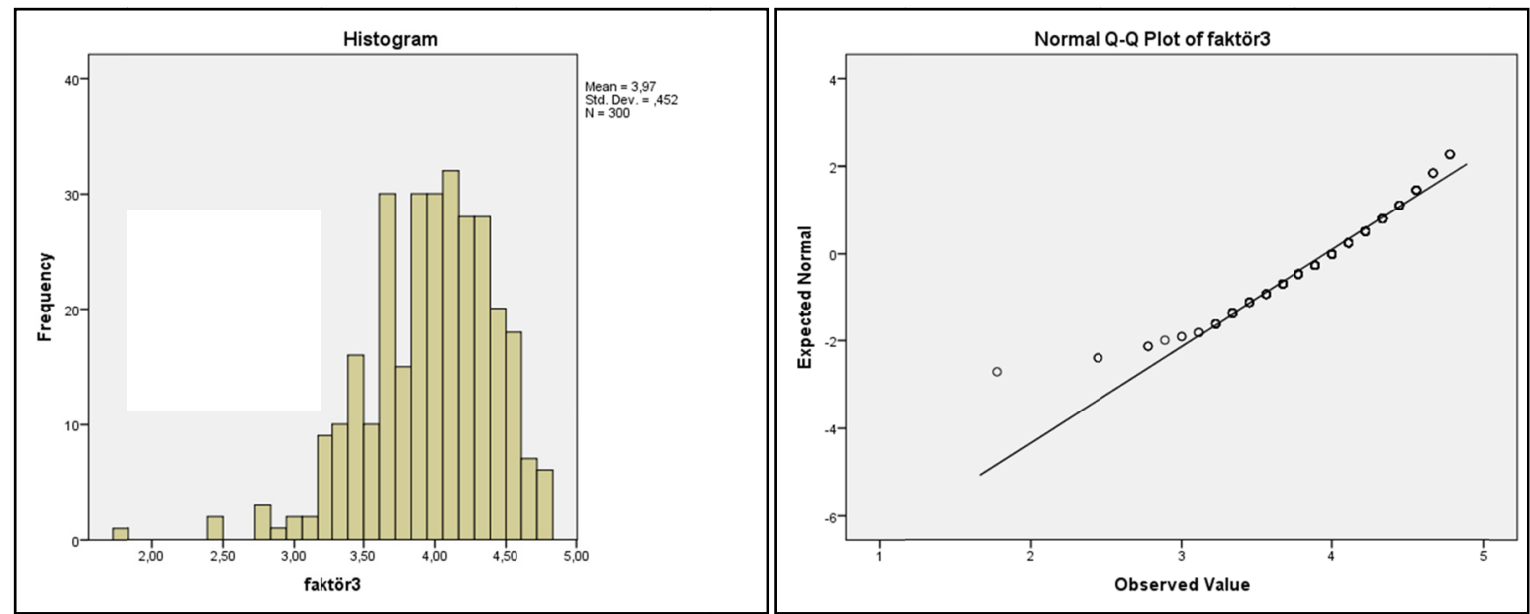

Figure 3. Factor 3 normal distribution charts for Honesty and Sharing Dimension
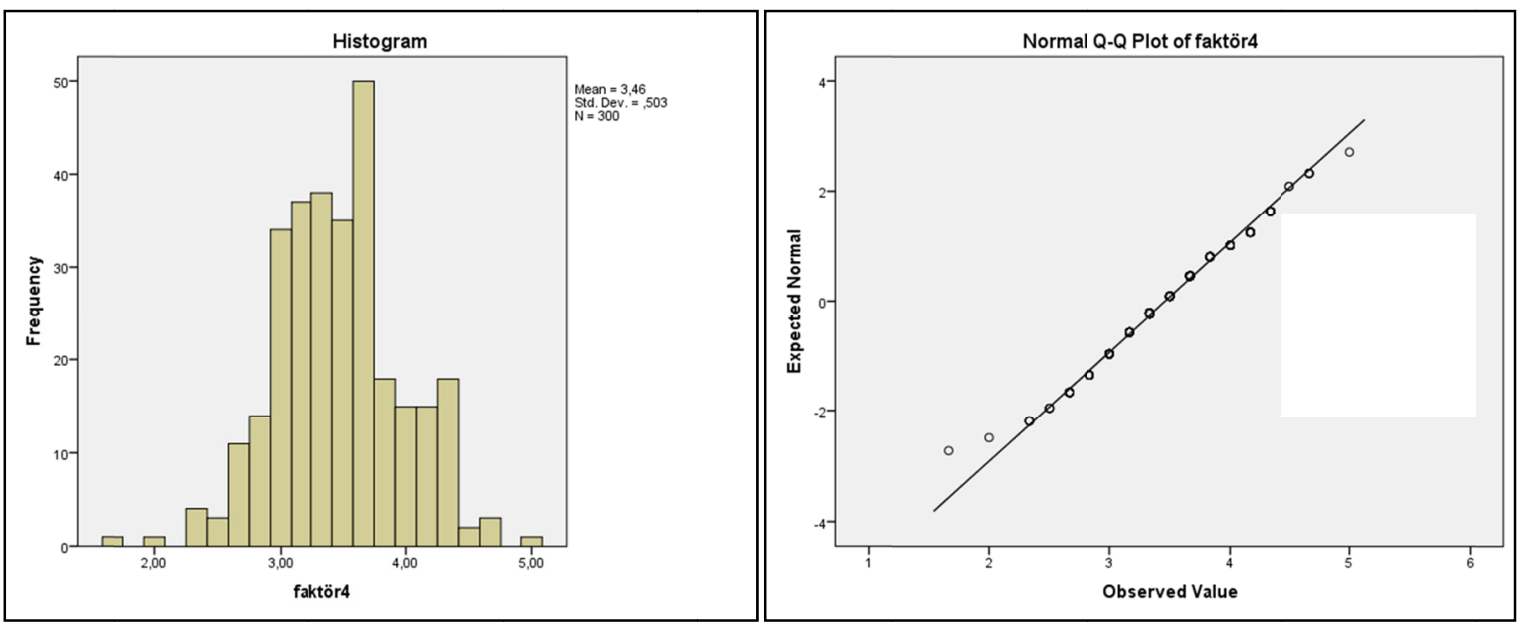

Figure 4. Factor 4 normal distribution charts for Respect and Truth Dimension 

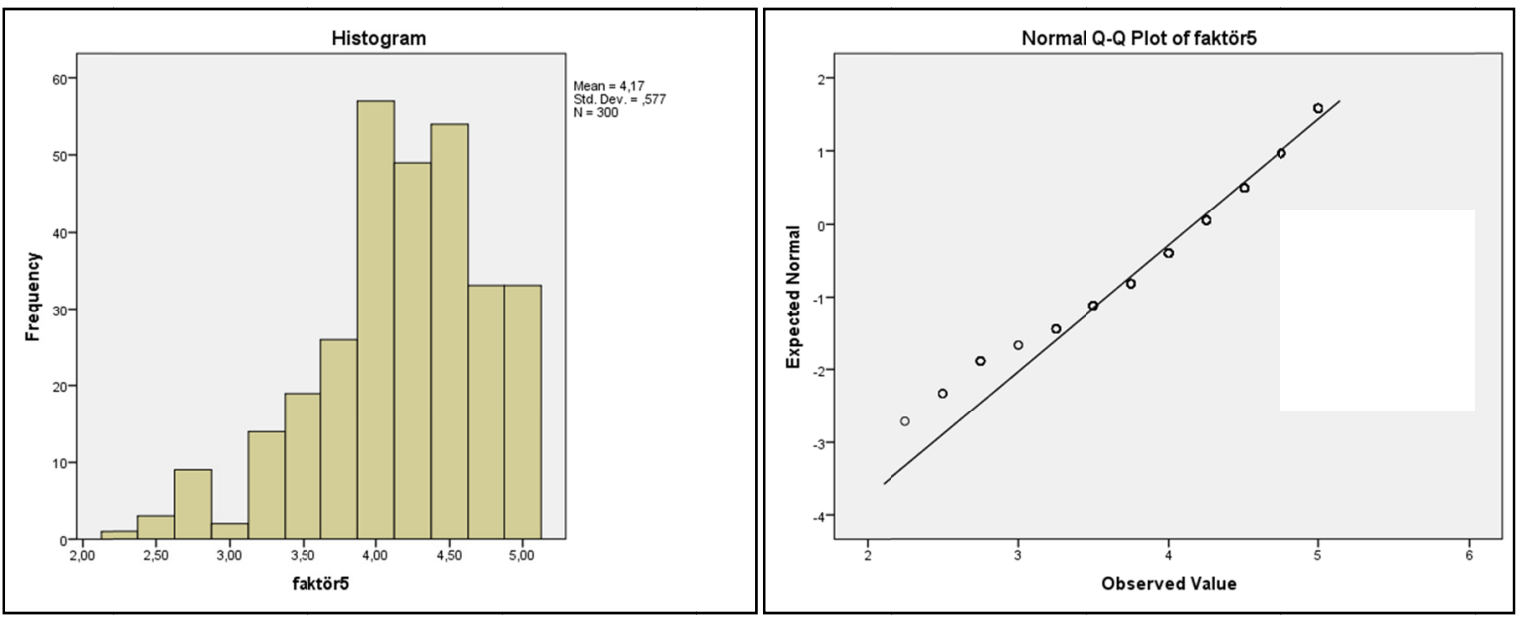

Figure 5. Factor 5 normal distribution charts for Sharing and Respect Dimension

According to the charts given for the 5 sub-dimensions of the individual values inventory above, a normal distribution is observed in all dimensions. 


\section{Results}

Table 1. Demographic information of the sample group

\begin{tabular}{|c|c|c|c|}
\hline & & $f$ & $\%$ \\
\hline \multirow[t]{5}{*}{ Age } & $20-25$ & 7 & 2.3 \\
\hline & $26-30$ & 41 & 13.7 \\
\hline & $31-35$ & 56 & 18.7 \\
\hline & $36-40$ & 66 & 22.0 \\
\hline & 41 and above & 130 & 43.3 \\
\hline \multirow[t]{2}{*}{ Gender } & Female & 139 & 46.3 \\
\hline & Male & 161 & 53.7 \\
\hline \multirow[t]{3}{*}{ Marital Status } & Married & 224 & 74.7 \\
\hline & Single & 60 & 20.0 \\
\hline & Other & 16 & 5.3 \\
\hline \multirow[t]{3}{*}{ Educational Status } & Associate's Degree & 15 & 5.0 \\
\hline & Bachelor's Degree & 233 & 77.7 \\
\hline & Master's Degree & 52 & 17.3 \\
\hline \multirow{5}{*}{ Total Experience in Working Life } & Less than a year & 9 & 3.0 \\
\hline & $1-5$ years & 62 & 20.7 \\
\hline & $6-10$ years & 82 & 27.3 \\
\hline & $11-20$ Years & 122 & 40.7 \\
\hline & 21 years and above & 25 & 8.3 \\
\hline \multirow[t]{2}{*}{ Job Position } & Contracted & 33 & 11.0 \\
\hline & Permanent & 267 & 89.0 \\
\hline \multirow[t]{5}{*}{ Settlement to Which the Institution is Linked } & Village & 28 & 9.3 \\
\hline & Town & 13 & 4.3 \\
\hline & District & 32 & 10.7 \\
\hline & City Center & 199 & 66.3 \\
\hline & Metropolis & 28 & 9.3 \\
\hline \multirow[t]{2}{*}{ Does He/She Do Exercise? } & Yes & 150 & 50.0 \\
\hline & No & 150 & 50.0 \\
\hline \multirow[t]{4}{*}{ Time Allocated for Exercise in a Week } & None & 146 & 48.7 \\
\hline & $2-4$ hours & 103 & 34.3 \\
\hline & $5-8$ hours & 44 & 14.7 \\
\hline & 9 hours or more & 7 & 2.3 \\
\hline \multirow[t]{4}{*}{ What Does He/She Prefer Doing in His/Her Spare Time? } & Reading a book & 140 & 46.7 \\
\hline & Going to the cinema & 50 & 16.7 \\
\hline & Visiting historical places & 47 & 15.7 \\
\hline & Going to entertainment venues & 63 & 21.0 \\
\hline \multirow[t]{4}{*}{ How Often Does He/She Read? } & Once in a week & 113 & 37.7 \\
\hline & Every two weeks & 96 & 32.0 \\
\hline & Reading a book rarely & 82 & 27.3 \\
\hline & Never & 9 & 3.0 \\
\hline \multirow[t]{4}{*}{ How Does He/She Define Himself/Herself in Daily Life? } & Calm & 89 & 29.7 \\
\hline & Social and extrovert & 143 & 47.7 \\
\hline & Hyperactive (energetic) & 43 & 14.3 \\
\hline & Angry and hot-blooded & 25 & 8.3 \\
\hline
\end{tabular}

According to Table 1, almost half (43.3\%) of the participants are 41 years and above. The gender distributions of the participants are similar. $74.7 \%$ of the teachers are married and $20.0 \%$ are single. Considering their educational backgrounds, $77.7 \%$ have bachelor's degree and $17.3 \%$ have master's degree. Considering their total experience in working life, it is seen that a majority of $40.7 \%$ is between $11-20$ years, $20.7 \%$ is between $1-5$ years and $27.3 \%$ is between $6-10$ years. It is observed that $89.0 \%$ of the teachers participating in the research are permanent teachers, $11.0 \%$ are contracted teachers and $66.3 \%$ of them work in the city center. The teachers' rates of doing and not doing exercise are half and half. While $34.3 \%$ of the teachers allocate $2-4$ hours for sports per week, $14.7 \%$ of them allocate $5-8$ hours. While the rate of the teachers who read books in their spare time is $46.7 \%$, the rate of those who go to the cinema is $16.7 \%$, the rate of those who visit historical places is $15.7 \%$ and the rate of those who go to entertainment venues is $21.0 \%$. While $37.7 \%$ of the teachers read books once a week, $32.0 \%$ of them read every two weeks and $27.3 \%$ of them read rarely. $29.7 \%$ of the teachers define themselves as calm, $47.7 \%$ define themselves as social and extrovert and $14.3 \%$ define themselves as energetic. 
Table 2. Mean and standard deviation values of the individual values inventory of the sample group

\begin{tabular}{llll}
\hline & $\mathrm{N}$ & Mean & $\mathrm{Sd}$ \\
\hline Factor 1- Discipline and Responsibility (16 items) & 300 & 4.15 & 0.47 \\
Factor 2- Trust and Forgiveness (12 items) & 300 & 3.10 & 0.54 \\
Factor 3- Honesty and Sharing (9 items) & 300 & 3.97 & 0.45 \\
Factor 4- Respect and Truth (6 items) & 300 & 3.46 & 0.50 \\
Factor 5- Sharing and Respect (4 items) & 300 & 4.17 & 0.58 \\
\hline
\end{tabular}

According to Table 2, the mean and standard deviation values related to the individual values perceptions of the teachers participating in the research were obtained as $x=4.15 \pm 0.47$ as the general mean for the discipline and responsibility dimension consisting of 16 items and this corresponds to the I agree value according to the 5-point likert scale range values. For the trust and forgiveness dimension consisting of 12 items, $x=3.10 \pm 0.54$ was obtained as the general mean and according to the 5-point likert scale range values, this corresponds to the I am undecided value. For the honesty and sharing dimension consisting of 9 items, $x=3.97 \pm 0.45$ was obtained as the general mean and according to the 5-point likert scale range values, this corresponds to the $\mathbf{I}$ agree value. For the respect and truth dimension consisting of 6 items, $x=3.46 \pm 0.50$ was obtained as the general mean and according to the 5-point likert scale range values, this corresponds to the $\mathbf{I}$ agree value. For the sharing and respect dimension consisting of 4 items, $x=4.17 \pm 0.58$ was obtained as the general mean and according to the 5 -point likert scale range values, this corresponds to the $\mathbf{I}$ agree value.

Table 3. Sample group's $t$ test results showing the evaluation of the teachers' perceptions of individual values in their workplaces by gender variable

\begin{tabular}{|c|c|c|c|c|c|}
\hline & Gender & $\mathrm{N}$ & Mean & $\mathrm{Sd}$ & $\mathrm{P}$ \\
\hline \multirow[t]{2}{*}{ Factor 1- Discipline and Responsibility } & Female & 139 & 4.19 & 0.48 & 0.200 \\
\hline & Male & 161 & 4.12 & 0.47 & \\
\hline \multirow[t]{2}{*}{ Factor 2- Trust and Forgiveness } & Female & 139 & 3.02 & 0.51 & $0.018 * *$ \\
\hline & Male & 161 & 3.17 & 0.56 & \\
\hline \multirow[t]{2}{*}{ Factor 3- Honesty and Sharing } & Female & 139 & 3.97 & 0.46 & 0.873 \\
\hline & Male & 161 & 3.96 & 0.44 & \\
\hline \multirow[t]{2}{*}{ Factor 4- Respect and Truth } & Female & 139 & 3.42 & 0.50 & 0.162 \\
\hline & Male & 161 & 3.50 & 0.51 & \\
\hline \multirow[t]{2}{*}{ Factor 5- Sharing and Respect } & Female & 139 & 4.24 & 0.53 & $0.048 * *$ \\
\hline & Male & 161 & 4.11 & 0.61 & \\
\hline
\end{tabular}

Note. ${ }^{* *}$ It refers to a significant difference at the level of $\mathrm{P}<0.05$.

According to Table 3, in the light of the results of the $T$ test analysis where we examined the teachers' perceptions of individual values in their workplaces by the gender variable, significant differences were observed in the Trust and Forgiveness dimension and Sharing and Respect dimension. Accordingly, the male teachers' perception levels $(x=3.17 \pm 0.56)$ in the trust and forgiveness dimension were significantly higher than the levels $(x=3.02 \pm 0.51)$ of the female teachers $(p<0.05)$. On the other hand, the female teachers' perception levels $(x=4.24 \pm 0.53)$ in the sharing and respect dimension were significantly higher than the levels $(x=4.11 \pm$ $0.61)$ of the male teachers $(\mathrm{p}<0.05)$.

Table 4. Sample group's $t$ test results showing the evaluation of the teachers' perceptions of individual values in their workplaces by task type variable

\begin{tabular}{|c|c|c|c|c|c|}
\hline & Task Type & $\mathrm{N}$ & Mean & $\mathrm{Sd}$ & $\mathrm{P}$ \\
\hline \multirow[t]{2}{*}{ Factor 1- Discipline and Responsibility } & Contracted & 33 & 4.04 & 0.41 & 0.150 \\
\hline & Permanent & 267 & 4.17 & 0.48 & \\
\hline \multirow[t]{2}{*}{ Factor 2- Trust and Forgiveness } & Contracted & 33 & 3.28 & 0.53 & $0.042 * *$ \\
\hline & Permanent & 267 & 3.08 & 0.54 & \\
\hline \multirow[t]{2}{*}{ Factor 3- Honesty and Sharing } & Contracted & 33 & 3.96 & 0.39 & 0.896 \\
\hline & Permanent & 267 & 3.97 & 0.46 & \\
\hline \multirow[t]{2}{*}{ Factor 4- Respect and Truth } & Contracted & 33 & 3.40 & 0.59 & 0.483 \\
\hline & Permanent & 267 & 3.47 & 0.49 & \\
\hline \multirow[t]{2}{*}{ Factor 5- Sharing and Respect } & Contracted & 33 & 4.01 & 0.60 & 0.087 \\
\hline & Permanent & 267 & 4.19 & 0.57 & \\
\hline
\end{tabular}

Note. $* *$ It refers to a significant difference at the level of $\mathrm{P}<0.05$. 
According to Table 4, in the light of the results of the T test analysis where we examined the teachers' perceptions of individual values in their workplaces by the task type variable, significant differences were only observed in the Trust and Forgiveness dimension. Accordingly, the contracted teachers' perception levels $(\mathrm{x}=$ $3.28 \pm 0.53)$ in the trust and forgiveness dimension were significantly higher than the levels $(x=3.08 \pm 0.54)$ of the permanent teachers $(\mathrm{p}<0.05)$.

Table 5. Sample group's one-way anova test results showing the evaluation of the teachers' perceptions of individual values in their workplaces by marital status variable

\begin{tabular}{|c|c|c|c|c|c|c|c|}
\hline & Marital Status & $\mathrm{N}$ & Mean & $\mathrm{Sd}$ & $\mathrm{F}$ & $\mathrm{P}$ & Difference \\
\hline Factor 1- Discipline and & Married & 224 & 4.18 & 0.47 & 2.336 & 0.098 & \\
\hline \multirow[t]{2}{*}{ Responsibility } & Single & 60 & 4.04 & 0.46 & & & \\
\hline & Other & 16 & 4.21 & 0.53 & & & \\
\hline \multirow[t]{3}{*}{ Factor 2- Trust and Forgiveness } & Married & 224 & 3.04 & 0.57 & 5.241 & $0.006 * *$ & $1-2$ \\
\hline & Single & 60 & 3.28 & 0.44 & & & \\
\hline & Other & 16 & 3.24 & 0.36 & & & \\
\hline \multirow[t]{3}{*}{ Factor 3- Honesty and Sharing } & Married & 224 & 3.97 & 0.46 & 1.358 & 0.259 & \\
\hline & Single & 60 & 3.91 & 0.40 & & & \\
\hline & Other & 16 & 4.12 & 0.47 & & & \\
\hline \multirow[t]{3}{*}{ Factor 4- Respect and Truth } & Married & 224 & 3.45 & 0.49 & 0.278 & 0.757 & \\
\hline & Single & 60 & 3.51 & 0.56 & & & \\
\hline & Other & 16 & 3.46 & 0.53 & & & \\
\hline \multirow[t]{3}{*}{ Factor 5- Sharing and Respect } & Married & 224 & 4.21 & 0.58 & 3.902 & $0.021 * *$ & $1-2$ \\
\hline & Single & 60 & 3.99 & 0.56 & & & \\
\hline & Other & 16 & 4.31 & 0.51 & & & \\
\hline
\end{tabular}

Note. $* *$ It refers to a significant difference at the level of $\mathrm{P}<0.05$.

According to Table 5, in the light of the results of the one-way anova test analysis where we examined the teachers' perceptions of individual values in their workplaces by the marital status variable, significant differences were observed between the groups in the Trust and Forgiveness dimension and Sharing and Respect dimension. The single teachers' perception levels $(\mathrm{x}=3.28 \pm 0.44)$ in the trust and forgiveness dimension were significantly higher than the levels $(\mathrm{x}=3.04 \pm 0.57)$ of the married teachers $(\mathrm{p}<0.05)$. On the other hand, the married teachers' perception levels $(x=4.21 \pm 0.58)$ in the sharing and respect dimension were significantly higher than the levels $(x=3.99 \pm 0.56)$ of the single teachers $(\mathrm{p}<0.05)$.

Table 6. Sample group's one-way anova test results showing the evaluation of the teachers' perceptions of individual values in their workplaces by professional experience variable

\begin{tabular}{|c|c|c|c|c|c|c|c|}
\hline & Professional Experience & $\mathrm{N}$ & Mean & $\mathrm{Sd}$ & $\mathrm{F}$ & $\mathrm{P}$ & Difference \\
\hline Factor 1- Discipline and & Less than a year & 9 & 4.22 & 0.32 & 0.585 & 0.674 & \\
\hline \multirow[t]{4}{*}{ Responsibility } & $1-5$ years & 62 & 4.14 & 0.41 & & & \\
\hline & $6-10$ years & 82 & 4.10 & 0.46 & & & \\
\hline & $11-20$ Years & 122 & 4.20 & 0.52 & & & \\
\hline & 21 years and above & 25 & 4.14 & 0.48 & & & \\
\hline \multirow[t]{5}{*}{ Factor 2- Trust and Forgiveness } & Less than a year & 9 & 3.03 & 0.31 & 5.53 & $0.000 * *$ & $2-4$ \\
\hline & $1-5$ years & 62 & 3.33 & 0.47 & & & $2-5$ \\
\hline & $6-10$ years & 82 & 3.15 & 0.53 & & & \\
\hline & $11-20$ Years & 122 & 3.01 & 0.55 & & & \\
\hline & 21 years and above & 25 & 2.85 & 0.58 & & & \\
\hline \multirow[t]{5}{*}{ Factor 3- Honesty and Sharing } & Less than a year & 9 & 4.00 & 0.22 & 0.167 & 0.955 & \\
\hline & $1-5$ years & 62 & 3.98 & 0.42 & & & \\
\hline & $6-10$ years & 82 & 3.95 & 0.43 & & & \\
\hline & $11-20$ Years & 122 & 3.98 & 0.50 & & & \\
\hline & 21 years and above & 25 & 3.91 & 0.44 & & & \\
\hline \multirow[t]{5}{*}{ Factor 4- Respect and Truth } & Less than a year & 9 & 3.39 & 0.60 & 1.313 & 0.265 & \\
\hline & $1-5$ years & 62 & 3.54 & 0.58 & & & \\
\hline & $6-10$ years & 82 & 3.50 & 0.49 & & & \\
\hline & $11-20$ Years & 122 & 3.39 & 0.48 & & & \\
\hline & 21 years and above & 25 & 3.52 & 0.40 & & & \\
\hline \multirow[t]{5}{*}{ Factor 5- Sharing and Respect } & Less than a year & 9 & 4.14 & 0.50 & 2.459 & $0.046 * *$ & $3-4$ \\
\hline & $1-5$ years & 62 & 4.08 & 0.54 & & & \\
\hline & $6-10$ years & 82 & 4.06 & 0.54 & & & \\
\hline & $11-20$ Years & 122 & 4.29 & 0.62 & & & \\
\hline & 21 years and above & 25 & 4.16 & 0.52 & & & \\
\hline
\end{tabular}

Note. ** It refers to a significant difference at the level of $\mathrm{P}<0.05$. 
According to Table 6, in the light of the results of the one-way anova test analysis where we examined the teachers' perceptions of individual values in their workplaces by the professional experience variable, significant differences were observed between the groups in the Trust and Forgiveness dimension and Sharing and Respect dimension. The perception levels $(x=3.33 \pm 0.47)$ of the teachers with $1-5$ years of professional experience, in the trust and forgiveness dimension were significantly higher than the levels of the teachers with 11-20 years of professional experience $(\mathrm{x}=3.01 \pm 0.55)$ and the teachers with over 21 years of professional experience $(\mathrm{x}=$ $2.85 \pm 0.58)(\mathrm{p}<0.05)$. On the other hand, the perception levels of teachers with 11-20 years of professional experience $(\mathrm{x}=4.29 \pm 0.62)$ in the sharing and respect dimension were significantly higher than the teachers with $6-10$ years of professional experience $(\mathrm{x}=4.06 \pm 0.54)(\mathrm{p}<0.05)$.

Table 7. Sample group's one-way anova test results showing the evaluation of the teachers' perceptions of individual values in their workplaces by self-definition variable

\begin{tabular}{|c|c|c|c|c|c|c|c|}
\hline & Self-Definition & $\mathrm{N}$ & Mean & $\mathrm{Sd}$ & $\mathrm{F}$ & $\mathrm{P}$ & Difference \\
\hline Factor 1- Discipline and & Calm & 89 & 4.19 & 0.42 & 2.463 & 0.063 & \\
\hline \multirow[t]{3}{*}{ Responsibility } & Social and extrovert & 143 & 4.19 & 0.48 & & & \\
\hline & Hyperactive (energetic) & 43 & 4.07 & 0.48 & & & \\
\hline & Angry and hot-blooded & 25 & 3.95 & 0.58 & & & \\
\hline \multirow[t]{4}{*}{ Factor 2- Trust and Forgiveness } & Calm & 89 & 2.99 & 0.54 & 1.830 & 0.142 & \\
\hline & Social and extrovert & 143 & 3.13 & 0.57 & & & \\
\hline & Hyperactive (energetic) & 43 & 3.20 & 0.44 & & & \\
\hline & Angry and hot-blooded & 25 & 3.10 & 0.49 & & & \\
\hline \multirow[t]{4}{*}{ Factor 3- Honesty and Sharing } & Calm & 89 & 4.00 & 0.42 & 1.142 & 0.332 & \\
\hline & Social and extrovert & 143 & 3.98 & 0.46 & & & \\
\hline & Hyperactive (energetic) & 43 & 3.93 & 0.36 & & & \\
\hline & Angry and hot-blooded & 25 & 3.82 & 0.64 & & & \\
\hline \multirow[t]{4}{*}{ Factor 4- Respect and Truth } & Calm & 89 & 3.38 & 0.41 & 1.887 & 0.132 & \\
\hline & Social and extrovert & 143 & 3.50 & 0.53 & & & \\
\hline & Hyperactive (energetic) & 43 & 3.57 & 0.51 & & & \\
\hline & Angry and hot-blooded & 25 & 3.38 & 0.59 & & & \\
\hline \multirow[t]{4}{*}{ Factor 5- Sharing and Respect } & Calm & 89 & 4.30 & 0.52 & 6.109 & $0.000 * *$ & $1-3$ \\
\hline & Social and extrovert & 143 & 4.20 & 0.57 & & & $1-4$ \\
\hline & Hyperactive (energetic) & 43 & 3.95 & 0.60 & & & $2-4$ \\
\hline & Angry and hot-blooded & 25 & 3.88 & 0.61 & & & \\
\hline
\end{tabular}

Note. ${ }^{* *}$ It refers to a significant difference at the level of $\mathrm{P}<0.05$.

According to Table 7, in the light of the results of the one-way anova test analysis where we examined the teachers' perceptions of individual values in their workplaces by the self-definition variable, significant differences were only observed between the groups in the Sharing and Respect dimension. The perception levels of the teachers, who define themselves as calm $(x=4.30 \pm 0.52)$, in the sharing and respect dimension were significantly higher than the levels of the teachers who define themselves as hyperactive $(\mathrm{x}=3.95 \pm 0.60)$ and the teachers who define themselves as angry and hot-blooded $(\mathrm{x}=3.88 \pm 0.61)(\mathrm{p}<0.05)$. For the same factor, the perception levels of the teachers, who define themselves as social and extrovert $(x=3.20 \pm 0.57)$ were significantly higher than the levels of the teachers who define themselves as angry and hot-blooded $(\mathrm{x}=3.88 \pm$ $0.61)(\mathrm{p}<0.05)$.

\section{Discussion and Conclusion}

The mean and standard deviation values related to the individual values perceptions of the teachers participating in the research were obtained as $\mathrm{x}=4.15 \pm 0.47$ for the discipline and responsibility dimension consisting of 16 items and this corresponds to the I agree value according to the 5-point likert scale range values. For the trust and forgiveness dimension consisting of 12 items, $x=3.10 \pm 0.54$ was obtained as the general mean and according to the 5-point likert scale range values, this corresponds to the I am undecided value. For the honesty and sharing dimension consisting of 9 items, $\mathrm{x}=3.97 \pm 0.45$ was obtained as the general mean and according to the 5-point likert scale range values, this corresponds to the I agree value. For the respect and truth dimension consisting of 6 items, $x=3.46 \pm 0.50$ was obtained as the general mean and according to the 5-point likert scale range values, this corresponds to the I agree value. For the sharing and respect dimension consisting of 4 items, $x=4.17 \pm 0.58$ was obtained as the general mean and according to the 5-point likert scale range values, this corresponds to the I 
agree value. When the literature is examined, it is possible to encounter studies analyzing the relationship between the socio-demographic variables (gender, marital status, age, educational level, family income) and attitudes or consumptions of the consumers having environmental consciousness (Balderjahn, 1988; Straughan \& Roberts, 1999; Tilikidou \& Delistavrou, 2001; Vaizoglu et al., 2005; Yaras et al., 2011).

When the results obtained regarding the teachers' "perceptions of individual values in their workplaces were examined by the gender variable, significant differences were observed in the trust and forgiveness dimension and the sharing and respect dimension. Accordingly, male teachers" perception levels in the trust and forgiveness dimension were significantly higher then to the levels of the female teachers. In their study, Kolaç and Karadağ (2012) state that regardless of gender, teachers give priority to the values of honesty, trust and respect (Kolac \& Karadag, 2012). On the other hand, the perception levels of the female teachers in the sharing and respect dimension were significantly higher than the levels of the male teachers.

According to the results of the $\mathrm{T}$ test analysis where we examined the teachers' perceptions of individual values in their workplaces by the task type variable, significant differences were observed only in the trust and forgiveness dimension. In the research, it is important to strengthen common values so that societies can continue their lives together in a sustainable way (Acar, 2016; Gozum, 2019). Accordingly, the perception levels of the contracted teachers in the trust and forgiveness dimension were significantly higher than the levels of the permanent teachers. Another study, emphasised that knowledge is not independent of cultural environment, traditions and values (Akbas, 2008).

According to the results of the one-way anova test analysis where we examined the teachers' perceptions of individual values in their workplaces by the marital status variable, significant differences were observed between the groups in the trust and forgiveness dimension and the sharing and respect dimension. The perception levels of the single teachers in the trust and forgiveness dimension were significantly higher than the levels of the married teachers. On the other hand, the perception levels of the married teachers in the sharing and respect dimension were significantly higher than the levels of the single teachers. In his study, Schwartz (2012) handles values and the relationships between these values as a whole and proposed a structure including the system of values (Acar, 2015; Schwartz, 2012).

According to the results of the one-way anova test analysis where we examined the teachers' perceptions of individual values in their workplaces by the professional experience variable, significant differences were observed between the groups in the trust and forgiveness dimension and the sharing and respect dimension. The perception levels of the teachers with one to five years of professional experience in the trust and forgiveness dimension were significantly higher than the levels of the teachers with eleven to twenty years of professional experience and the teachers with more than twenty one years of professional experience. On the other hand, the perception levels of teachers with with eleven to twenty years of professional experience in the sharing and respect dimension were significantly higher than the teachers with six to ten years of professional experience.

According to the examination of the teachers' perceptions of individual values in their workplaces by the self-definition variable, significant differences were observed only between groups in the sharing and respect dimension. The perception levels of the teachers, who define themselves as calm in the trust and forgiveness dimension were significantly higher than the levels of the teachers who defined themselves as hyperactive and the teachers who defined themselves as angry and hot-blooded. For the same factor, the perception levels of the teachers, who defined themselves as sociable and extroverted were significantly higher than the levels of the teachers who define themselves as angry and hot-blooded.

\section{References}

Acar, G. (2015). Impact of Personal Justice Perceptions of Students at the Faculty of Sport Sciences on Their Decision-Making Level. Anthropologist, 19(3), 627-632. https://doi.org/10.1080/09720073.2015.11891697

Acar, G. (2016). Investigation into the Perception of Physical Education Teachers on the Ethical Climate in their Workplace. International Journal of Educational Science, 13(2), 145-151. https://doi.org/10.31901/24566322.2016/13.02.01

Akbas, O. (2008). Deger Egitimi Akimlarina Genel Bir Bak1s. Degerler Egitimi Dergisi, 6, 9-27.

Allport, G. W., Vernon, P. E., \& Lindzey, G. (1960). Study of values: A scale for measuring the dominant interests in personality. Houghton Mifflin. Boston, MA.

Asan, T., Eksi, F., Dogan, A., \& Eksi, H. (2012). Bireysel degerler envanteri'nin dilsel esdegerlik gecerlik ve Guvenirlik Calısması. Marmara Universitesi Ataturk Egitim Fakultesi Egitim Bilimleri Dergisi, 27, 15-38. 
Balderjahn, I. (1988). Personality Variables and Environmental Attitudes as Predictors of Ecologically Responsible Consumption Patterns. Journal of Business Research, 17, 51-56. https://doi.org/10.1016/0148-2963(88)90022-7

Basol, O., Bilge, E., \& Kuzgun, S. (2012). A Research for Determining of Career Values of Students: Personal Values. Electronic Journal of Vocational Colleges, 2(2), 57-68.

Feather, N. T. (1991). Variables relating to allocationof pocket money of children: Parental reasons and values. British Journal of Social Psychology, 30(1), 221-234. https://doi.org/10.1111/j.2044-8309.1991.tb00940.x

Gozum, P. (2019). Is Tatmini ve Etik İklim Perspektifinden Ogretmenler Ozelinde Bir Arastırma. Mehmet Akif Ersoy Universitesi Iktisadi ve Idari Bilimler Fakultesi Dergisi, 6, 230-245. https://doi.org/10.30798/makuiibf.516674

Hofstede, G. (2001). Culture's Consequences: Comparing Values, Behaviours, Institutions and Organizations Across Nations. Thousand Oaks, CA: Sage.

Kluckhohn, C. (1951). Values and Value Orientations in the Theory of Action, Toward A General Theory of Action. Harvard University Press.

Kolac, E., \& Karadag, R. (2012). Turkce Ogretmeni Adaylarının “Deger” Kavramına Yukledikleri Anlamlar ve Deger Siralamalari. Ilkogretim Online, 11, 762-777.

Rokeach, M. (1973). The Nature of Human Values. NewYork: The Free Press.

Roy, A. (2003). Factor Analysis and Initial Validation of the Personal Values Inventory. Unpublished Doctorate Dissertation, Tennessee State University, Usa.

Sayrac, N. (2016). Aile ve Bireysel Degerlerin Sorumlu Tuketim Bilinci Uzerindeki Etkisi. Unpublished Master Thesis, Istanbul Ticaret Universitesi, Sosyal Bilimler Enstitusu.

Schwartz, S. H. (1992). Universal's in the Content and Structure of Value: Theoretical Advances and Emprical Tests in 20 Countries; Advances in Experimental. The Journal of Social Psychology, 25, 1-65. https://doi.org/10.1016/S0065-2601(08)60281-6

Schwartz, S. H. (2012). An overview of the Schwartz theory of basic values. Online Readings in Psychology and Culture, 2, 1-20. https://doi.org/10.9707/2307-0919.1116

Smith, M. B. (1969). Social Psychology and Human Values (25th ed.). Chicago: Adline Publishing Company.

Straughan, R. D., \& Roberts, J. A. (1999). Environmental Segmentation Alternatives: A Look at Green Consumer Behavior in The New Millennium. Journal of Consumer Marketing, 16, 558-575. https://doi.org/10.1108/07363769910297506

Tekeli, S. (2017). Bireysel Degerlerin Marka Kisiligi, Markaya Yonelik Tutum ve Marka Sadakati Algisi Uzerine Etkisi: Allsveris Merkezi Orneği. Unpublished Master Thesis, Toros Universitesi, Sosyal Bilimler Enstitusu.

Tilikidou, I., \& Delistavrou, A. (2001). Utilization of Selected Demographics and Psychographics in Recycling Behavior Understanding: A Focus on Materialism. Greener Management International Journal, 34, 75-93. https://doi.org/10.9774/GLEAF.3062.2001.su.00008

Vaizoglu, S., Altıntas, H., Temel, F., Ahrabi, A. F., Aydogan, D., Bostanci, S., \& Güler, C. (2005). Tip Fakultesi Son Sinif Ogrencilerinin Cevre Bilincinin Degerlendirilmesi. TSK Koruyucu Hekimlik Bulteni, 4, 151-171.

Yaras, E., Eyup, A., \& Sakacı, B. K. (2011). Tuketicilerin Cevre Bilinci Duzeylerini Belirlemeye Yonelik Bir Arastirma. Oneri Dergisi, 9, 117-126.

\section{Copyrights}

Copyright for this article is retained by the author, with first publication rights granted to the journal.

This is an open-access article distributed under the terms and conditions of the Creative Commons Attribution license (http://creativecommons.org/licenses/by/4.0/). 